\title{
Akwantukese Festival of the New Juaben People: The Artforms and Their Aesthetics
}

\author{
Linda Armah $^{*} \quad$ Dr. Joe Adu-Agyem Dr. Mavis Osei \\ Department of Educational Innovations in Science and Technology, \\ Kwame Nkrumah University of Science and Technology, \\ P. O. Box UP 79, Kumasi - Ashanti Region, Ghana
}

\begin{abstract}
Aesthetics play a vital role in the celebration of Akwantukese festival. In the course of the festival celebration, several visual art forms are seen and these art forms give aesthetic value to observers. The aesthetic value associated to the visual art forms in the festival can aid people acquire knowledge and satisfaction. Yet, very few people actively participate in the celebration and do a critical observation of these visual art forms. The study is therefore aimed at focusing the aesthetic values of the visual art forms in the Akwantukese festival celebration. The objective(s) of the study are: (i)to identify the visual art forms embedded in the festival celebration. (ii)to describe the visual art forms and bring out their aesthetic values. Phenomenology and descriptive methods under qualitative research approach was employed in this study. The purposive sampling technique was used to select 30 respondents for the research and the main research instruments used for data collection were interviews and observations. The results indicate that there are a lot of visual art forms seen in Akwantukese festival celebration that have aesthetic values and can be appreciated by all and sundry. The research concludes that some of the art forms used during the festival celebration have philosophical and symbolical meanings that express emotions such as happiness, dreadfulness, sadness and others. It is therefore recommended that the chiefs and the people of New Juaben Traditional area should try as much as possible to fully participate in the festival celebration in order to see the various visual art forms and appreciate their aesthetic values. Again the festival should be made attractive to the international communities in order to promote tourism.
\end{abstract}

Keywords: Aesthetic values, art forms, performing art, Akwantukese festival, visual art, celebration

DOI: $10.7176 / \mathrm{ADS} / 80-04$

Publication date: January $31^{\text {st }} 2020$

\subsection{Introduction}

Aesthetic value, according to Kieran (2010), is the worth that an object or event has in the virtue of its ability to produce pleasure; this pleasure may be positive or negative. They aver that if any artwork or event offers pleasure in the virtue of experience such as beauty, elegance, gracefulness, harmony, proportion, unity, balance and others, then the artwork is said to have positive aesthetic value. The authors further added that if an artwork or event provides displeasure in the virtue of ugliness, abnormality or unpleasantness, grotesqueness, absurd, formlessness and others, then one can say that the artwork or event has negative aesthetic value. Aesthetic value according to Prinz (2007) is the emotions or feelings that an object or event arouses. The author again mentioned that the emotions can either be negative or positive during aesthetic appreciation. He further expressed that aesthetic value also depends on the design qualities that an artwork or artefact possesses. Such design qualities may be balance, originality, shape, colour, texture, rhythm and others. Prinz concluded that good art work can bring about negative emotions while bad art work can also elicit positive emotions which can lead to aesthetic pleasure.

According to Aumann (2014) aesthetic value depends on aesthetic properties such as beauty, grace, sadness, ugliness, elegance enables one to assess an artwork properly. He further mentioned that an object can have aesthetic value whether it has good or bad properties. For instance, if a work of art is beautiful, poignant or bold, it is said to have positive aesthetic value. But if it has attributes like dull, derivative or uninteresting, then it has a negative aesthetic value.

During Akwantukese festival celebration, a lot of visual art forms are seen and these art forms possess aesthetic values. In endorsing this, Osei-Bonsu (2010) and Stuhr (1994) indicated that the visual art forms which are always seen during festivals, durbars and other traditional ceremonies have aesthetic values. They added that these visual art forms have some aesthetic values, and are also functional in the sense that they play vital role in the traditional societies. The authors further clarified that the visual art forms are representational and express essential elements in life.

In the same vein, the visual art forms that are seen during Akwantukese festival also have aesthetic values and also express the culture and the life of the people of the New Juaben Traditional area. The problem is that there a lot of aesthetic values associated with the visual art forms embedded in the Akwantukesse festival celebration. Yet, very few people actively participate in the celebration to acknowledge the aesthetic values of these visual art forms. This study therefore intends to identify the visual art forms in the festival celebration and 
then bring out their aesthetic values.

\subsection{Methodology}

The study was conducted in the New Juaben Traditional area of the Eastern Region of Ghana. The research made use of qualitative design techniques. Phenomenology and descriptive study were the main research methods used by the researchers. According to Terrell (2016), phenomenological research method allows a researcher to observe a particular phenomenon he or she is researching on and get a better understanding of it. Kafle (2011) and Maggs-Rapport (2000) put forward that phenomenology is one of the qualitative research types which gives description of a phenomena and then bring out the unknown meanings and the importance of that particular occurrence. The authors further affirm that phenomenology aims at creating rich and deep interpretation of a phenomenon through instinct and focuses on the relevant knowledge. The descriptive method was appropriate in the sense that it helped the researcher to use participant observation to observe the various activities that went on during the Akwantukese festival celebration. Also, this method aided the researcher to describe the activities of the festival vividly and give meanings to the phenomena being studied. In addition, the descriptive method was apt because it enabled the researcher to use triangulation to gather needed data for the study.

The research instruments used in gathering data during the study were interviews, observations, and focus group discussions. In-depth personal interviews were conducted with the chiefs, sub-chiefs and queen mothers. The elderly persons and the youth were also engaged in focus group discussions, where their experiences regarding the aesthetic values of the visual art forms in the festival's celebration were solicited for. As a nonparticipant observer, the researcher was able to record the events and the phenomena under study without any distractions (Kumekpor, 2002).

Purposive sampling techniques was employed to select 30 respondents, which comprised 3 chiefs, 3 subchiefs, 2 queen mothers, 12 elderly men and women, and 10 youth who have witnessed the festival for the past five years or more. These people were selected based on the in-depth knowledge they have about the festival celebration. Creswell (2012) and Sandelowki (2000) opine that purposive sampling is appropriate in a study of this nature because it helped the researcher to obtain the needed information for the study.

\subsection{Results and Discussions}

\section{Visual or Environmental Art forms in Akwantukese}

Visual or Environmental art forms are all creative or artistic products that are perceived with the sense of sight (eye), sense of touch (skin) and emotions (heart). In other words, any creative product that one can see, touch, and which has the tendency to stimulate one's feelings is a visual art form (Amenuke, et al.1991). When it comes to Akwantukese festival celebration, a lot of visual art forms are displayed and examples of such visual art forms are chief's paraphernalia such as; palanquins, umbrellas, stools, chairs, pots, clothes, drums, headgears, linguist staffs, swords, rings, bangles, charms, talisman's and bracelets. Below are some of the various visual art forms seen in the celebration.

\section{Sword Bearer's Hat (Ntakrakye)}

The Omanhene (paramount chief) is an important personality in the New Juaben Traditional area; and for that matter, he attends a number of functions including festivals. When he is going for such functions, sword bearers lead and guard him. The relic in Figure. 1 is the sword bearer's hat known as ntakrakye in the Akan language. This sword bearer's headdress is well-designed and ostentatious and normally used during the Akwantukese festival celebration. According to the Abrasehene (chief in charge of sword bearers) this type of sword bearer's hat is worn by the mpomponsuo sword bearer whenever the Omanhene is attending important occasions such as festivals and durbars. To support the Abrasehene's affirmation, Osei-Bonsu (2010) and McLeod (1981) also mentioned that ntakrakye, which is the sword bearer's hat, is worn by mpomponsuo sword bearer. The main body of the hat is made of buffalo skin, gold and silver aluminum foil. The materials which are used to decorate the hat makes it awe-inspiring. More so, the plain weave technique used at the base of the hat makes it look gorgeous. It was observed that eagle feathers have been attached to the antelope's leather strap, and then affixed to the base of the hat. These feathers are creatively arranged in a falcate formation to suit the shape of the base. The black, brown and cream colours of the feather make the hat look elegant. Again, there is a pair of gold ram's horns in front of the hat which gives the hat an exquisite and splendid appearance. It was found out that the silver colour on the hat denotes pleasure, tranquility and pureness. The gold colour also stands for the wealth of the New Juaben state. Nana Kwame Tweneboa and Opanin Yaw Agyei assert that the sword bearer's hat communicates messages such as allegiance, endurance and strength of the New Juaben state.

The hat also has leather thongs and feathers attached to it. The leather thongs can be seen intricately knotted around charms, amulets and cowries. The arrangement, colours, texture and shape of the sword bearer's hat are in harmony and this makes it aesthetically pleasing and sustains one's interest.

It could be presumed that the feathers were arranged in hemispherical form to make the hat stand firm when one wears it. From observation, it could be said that the sword bearer's hat is mainly worn by people who are 
gigantic and physically strong and can protect the chief in times of dispute.

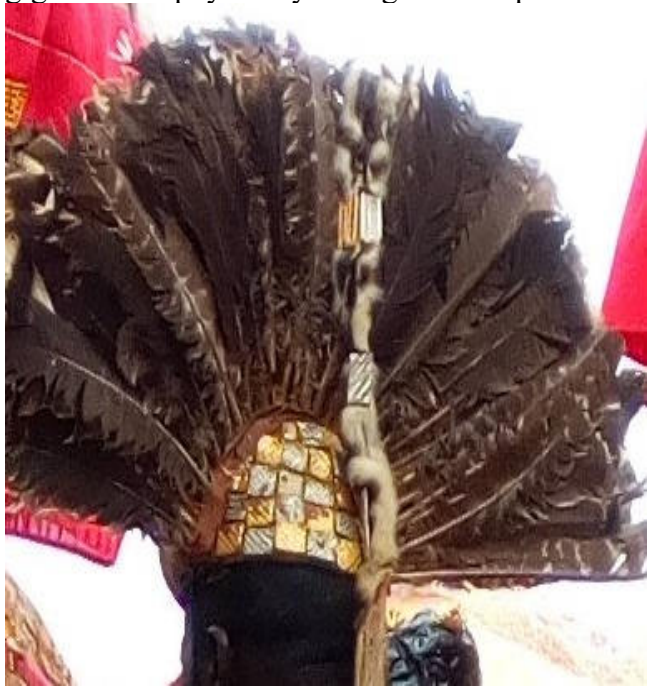

Source: Fieldwork

Figure .1a Sword bearer's hat (Ntakrakye) Back view

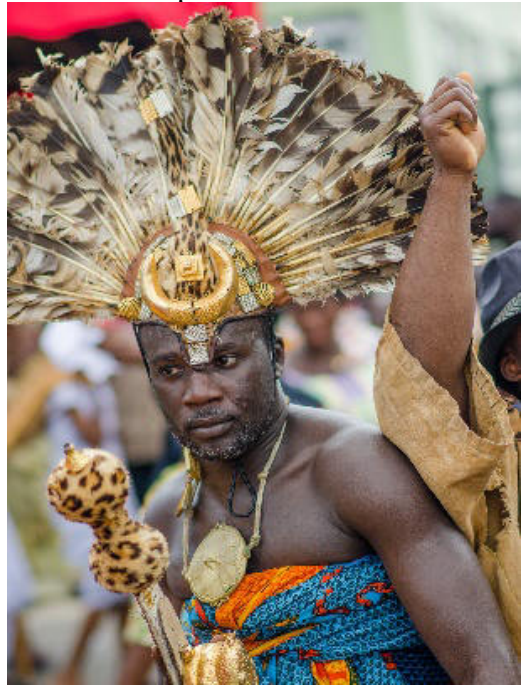

Source: Fieldwork
Figure 1b Sword bearer's
hat $($ Ntakrakye) Front view

\section{Palanquin(apakan)}

In the New Juaben Traditional area some chief's ride in palanquins during Akwantukese festival celebration. According to the respondents interviewed, when a chief ride in palanquin (see figure.2) during Akwantukese festival, it signifies that he is superior, powerful and has authority. In supporting this, Cudny (2016) mentioned in his study on the concept, origins and types of festivals that some chiefs mostly ride in palanquins during festivals to show their superiority and powers. The research revealed that the wood which was used in making this palanquin is "kusia" (nauclea diderrichii). The kusia tree is believed to be a strong tree which is endowed with some mystical powers that protect human beings and also give long life; that is why it is used in making palanquins for chiefs (Nana Asare-Baffoe, 2018, personal communication, 23 ${ }^{\text {rd }}$ June). The palanquin is cylindrical in shape and has two round poles supporting it. The poles are carved from the "esa" (celtis mildbraedii) tree, and it helps the palanquin to become firm and strong for carrying the chief. The palanquin is about $(8 \mathrm{ft})$ eight feet long and $(3 \mathrm{ft})$ three feet wide.

The palanquin is lined with a special blanket and fabric which makes the inside soft and comfortable to ride in. The wine-coloured fabric which is used to line the palanquin signifies the paramount chiefs' sadness. The linen and velvet fabrics used in stuffing the inside make it beautiful and attractive. All the colours used to decorate the palanquin have meanings. The red stands for the blood that their forefathers shed on the way from their ancestral home to the New Juaben. The gold signifies the riches and royalty of the New Juaben State, and the green depicts the scenic New Juaben environment and vegetation that promotes farming activities in the area. It was revealed that the black stand for the agony, suffering and problems that their ancestors faced during the journey to New Juaben. The elements and principles of design such as lines, balance, colour, shape and rhythm used in the decoration of the palanquin makes it aesthetically pleasing and excites emotions. An artefact which is properly designed with the necessary artistic qualities makes it appear beautiful, gives meaning and expresses emotion (Lope,2011). 


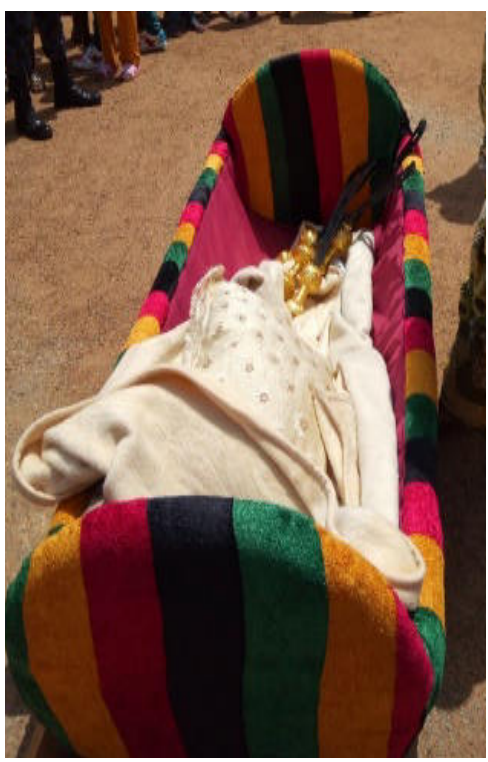

Figure.2: Palanquin(apakan)

\section{Chairs}

Source: Fieldwork

One of the visual art forms that is displayed during Akwantukese festival celebration are traditional chairs (see figure 3). According to respondents, these chairs represent the towns that comprise the New Juaben Traditional area. These towns are Suhyen, Jumapo, Oyoko, Asokore, Effiduase, Akwadum, Koforidua and Ada. The chairs are known as asipim and they are eight in number, which stands for the various towns. These chairs are used mainly on occasions such as festivals, durbars and even funerals. The study revealed that, there are two types of asipim and these are asipimtenten and asipimtia but the ones in plate 4.3 are asipimtia and are low armless chairs. The frames of the chairs were made from odum (milicia excels) wood.

These chairs are made from odum (milicia excelsa) and the reason is that it is the king of all woods and it is very strong. The odum tree also has spiritual powers that protect people and insect do not attack it and so when used for furniture it last longer. My uncle even told me that if you are king, chief or queen mother and you sit on odum stool or chair you will live longer (Nana Osei Kwasi, 2017, personal communication 28th October).

The chairs have both the back and seat covered with the skin of an antelope (adowa nwuma). The antelope skins are tightly stretched all over the frames of the eight chairs. The chairs convey messages and also symbolize the presence of the ancestors. The chairs are dark brown in colour, and have pieces of brass and golden metals attached to the back and these make the chairs look beautiful. The colour, arrangement, and shape of the chairs are all in harmony. These make the chairs look appealing to the eye of the observer. The chairs gathered together signifies that all the towns that comprise the New Juaben traditional area are united and there is peace among themselves.

It was observed that the chairs that have been arranged in a rectangular form makes the whole thing looks very beautiful. There is also unity and balance in the arrangement which expresses emotion and again send messages to the viewers. The fur which is on the chairs makes it look natural. It can be construed that the artist who produced the chairs want viewers to know that he really used natural skin. 


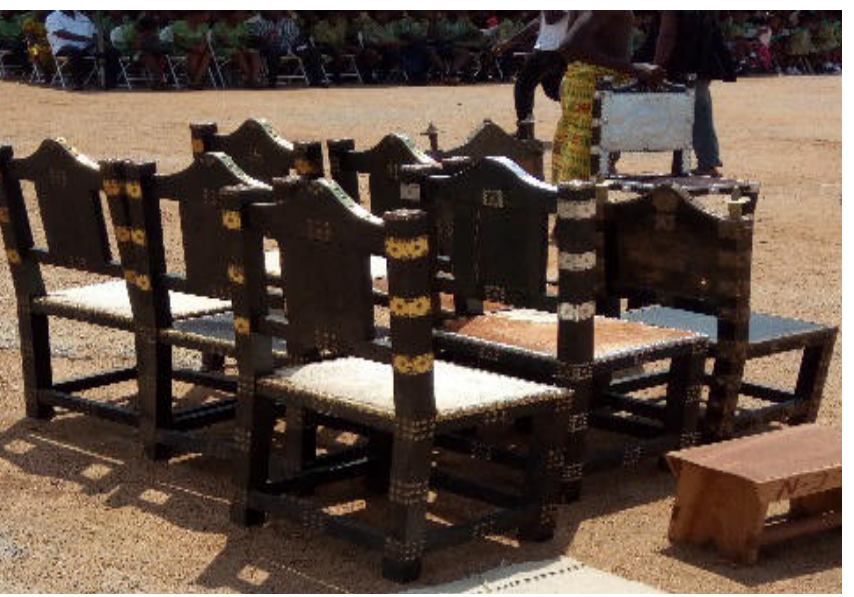

Figure.3 Asipimtia chairs

Source: Fieldwork

Stools (asesedwa)

In the New Juaben Traditional area, stools play very important role in their daily activities. The stools $(a s \varepsilon s \varepsilon d w a)$ displayed during Akwantukese festival celebration are mainly used by queen mothers. The odehye nsu adwa (a royal does not cry stool) and m'akoma so ade adwa (my heart desire stool) shown in Figures 4 . and 5 respectively are wooden stools classified under mmaa adwa (stools for women) and they are carved from nyame dua (alstonia boonei). These stools are composed of three parts, the base, the middle portion and the top. The " $m$ 'akoma so ade" stool has some adinkra symbols cut out from a silver plate and affixed to its facet, while the "mmaa adwa" stool has no design attached to it. Both stools have triangular holes created at their middle part. The study revealed that the stool is a significant symbol of Akan politics and also the source of all ancient traditions. Respondents further added that the stool symbolizes the soul, strength and spirit of the New Juaben state, and also serves as a bond between the people and their chiefs.

Likewise, Amenuke et al. (1991:151) also states that "the stool is the soul of the society and serves as a symbolic link between the common people in the society and the head. Every component part of the design of the stool represent one of the main ideas that make a perfect society."

Information gathered from respondents revealed that the stool is a symbol of unity among the people of the New Juaben state. They further stated that all the parts of the stool denote the features that make up a perfect society. The top of the stool which is shaped like the crescent or half-moon suggests the loving fondle of mother. Also, it represents the warmth of the female influence in our traditional society. The four rectangular shaped pillars stand for the male power, strength, prosperity and the independence of the chiefs and men in the New Juaben State. The pointed projections which are triangular also stand for the male children in the society because they have angular pointed bodies (Nana Yaw Annor Boateng, personal communication,2018, 17 ${ }^{\text {th }}$ June).

The respondents mentioned that the round projections on the stools represent the female children in the society while the strong central pillar in the middle of both stools showcase the existence of God. The strong central pillar explains the vital role that God plays in the society, thus His supremacy, protection and guidance. The small triangular holes signify the fairness and justice of God. Again, the base of the stool shows the support that the land has given to the people in the society. Such supports are the natural resources like gold, diamond, rivers, plants and animals. The silver symbols attached to the odehye nsu adwa stool in Figure 4 indicates the purity or cleanliness of the New Juaben state. This can be achieved when there is unity, love, peace and harmony. The stools also symbolize hospitality, wisdom, authority and continuity of life. Both stools are beautiful, dazzling and good looking, and the spiral and linear designs on them bring out their aesthetic qualities. The silver symbols attached to the stool in Figure.4 makes it look unique, fascinating, majestic and expresses emotions such as joy and happiness. Also, the silver buttons which are linearly used to decorate the base and top segments of the stool in figure 4 makes it look very attractive, aesthetically pleasing and awe-inspiring. The holes on both stools are unique, distinct and stunning. Besides, the semi-circular shapes around the pillars of the stools express the feeling of affection. From the aforementioned, it can be construed that the stool is a symbol of supremacy to the occupant and it links the members of the society as well as the ancestors. 


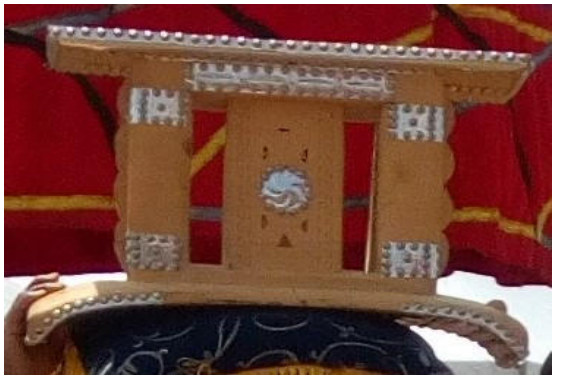

Figure 4 odehye nsu adwa

Source: Fieldwork

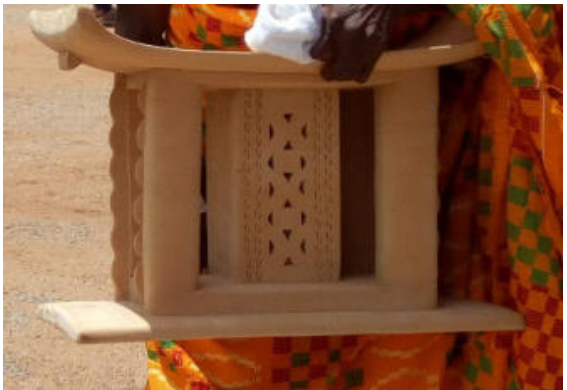

Figure 5 m'akoma so ade adwa Source: Fieldwork

Palm Wine Pots and Calabash Lids (frantaa)

One of the visual art forms that was seen at Akwantukese festival celebration was a group of ritual pots with calabashes on top. These ritual pots have been arranged in a circular form. The pots are made with clay and are circular in shape and they have thick round rim. Looking at the smoothness and its perfect roundedness, it could be deduced that the pots were fashioned by someone who has been burnishing pots for a long time and were fired by the open firing method. These pots contain palm wine known as "ntunkum" or "nsa kan". Thus, the first wine from the palm fruit. The pots are covered with calabashes to prevent dirt and insects from entering the palm wine. The wine is brought to the festival ground by the "nsafiesohene" (chief in charge of drinks) on behalf of the Omanhene (paramount chief). The sub chiefs and their subjects who come from different places are served with the palm wine. According to the respondents, the wine is used to welcome visitors to the New Juaben state, and to demonstrate their hospitality. Again, it came to light that this type of wine is used to offer libation to the gods and ancestors at baamu (royal cemetery) during the Akwantukese festival celebration to venerate them.

The calabashes on top of the ritual pots are used to drink the palm wine. It was established that the physical appearance of the pots in Plate 4.6 in totality, represent a joyful mood. The arrangement, colour, shape and design of the pots are also in harmony and rhythmic. The artist made use of elements of art such as curved lines, texture, colour and shape.

It was observed that the colours of both the pots and the calabash contrasted very well, and therefore pleasing to the eye. The dark brown interspersed with black colour of the pots suggests reliability, comfort, friendship and warmth. The composition and arrangement endorse the ideas of Jacquette (2014) and Gyekye (1996) that aesthetic value is achieved when artefacts, events and scenes express emotions, gives pleasure and also sustains people's interest.

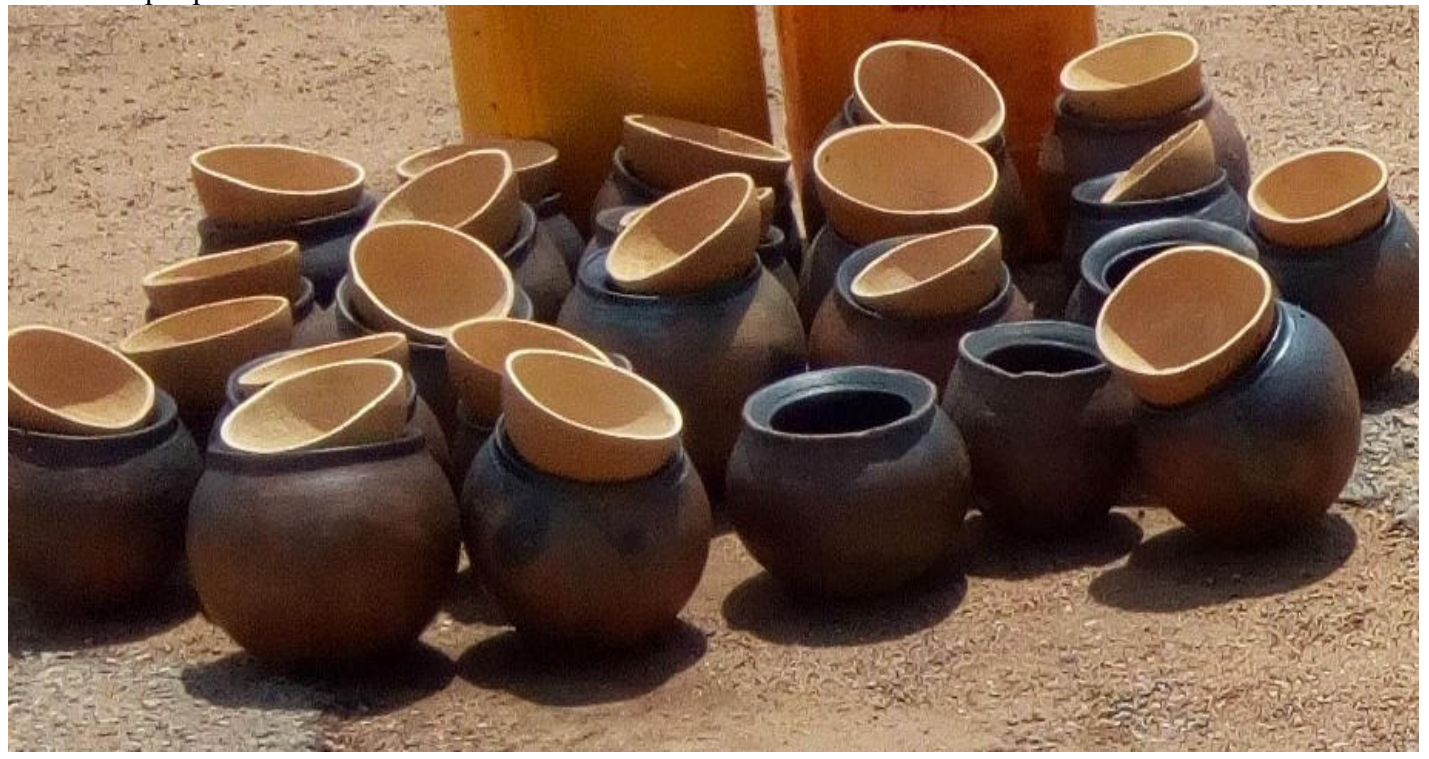

Fig.6: Palm wine pots with calabashes on top Source: Fieldwork

Yiadom-Hwedie, Oko Nti Headgear (Abotire)

On occasions such as durbars and festivals, the chiefs and traditional leaders who attend dress in a special way that make the event look colourful and attractive. In New Juaben Traditional area too, chiefs and traditional leaders dress gorgeously during the Akwantukese festival celebrations. As part of their dressing, they put on 
headgears which distinguishes them from other participants and observers. Plate 4.7 portrays one of the headgears that were displayed during the festival celebrations. It was observed that the fabric which was used to produce this particular headgear is black velvet (agoo). The headgear is black in colour with golden symbols attached to it makes look elegant. The golden symbols affixed to the headgear is known as "Yiadom -Hwedie, Oko nti" symbol. Again, the "H" and "Y" shapes in the middle of the symbol gives the headgear splendid look. The circular symbol on which the sword and gun are attached to has some meandering design which is creatively crafted and makes the headgear outstanding. The design and textures used in the formation of the symbol make it very striking and enhances its aesthetic appearance. The blend of gold and black colours have made this headgear stand out. The black fabric used for the headgear symbolizes the pain and agony that the people passed through when coming to New Juaben, while the sword and gun also signifies the wars that they fought. In addition, it was discovered that the symbols indicate that the New Juaben state is strong, powerful and resilient and that the power and authority of chiefs should not be underrated. Besides, the symbol also signifies that there is unity among the people of the New Juaben state. The combination of the sword and gun are balanced on the circular symbol and it appeals to the eye.

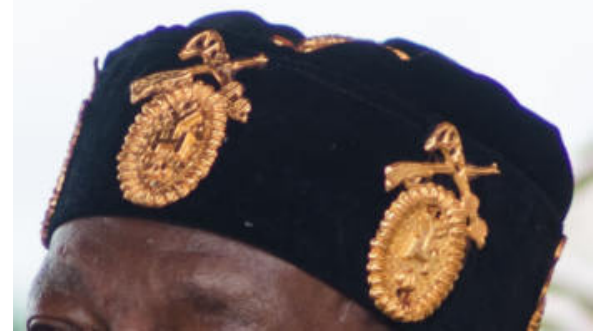

Figure.7: Black headgear with "Yiadom -Hwedie, Oko nti" symbols Source: Fieldwork

\section{A Red Headgear with Nfofoo Symbol}

The headgear in Figure. 8 has good design qualities which makes it look very handsome, striking and alluring. The symbols on it is known as nfofoo which is derived from a plant that has a yellow flower. According to Nana Obugya Asante, this headgear is known as "me tena ho mma nfofoo nnane me kwaye" which literary means one should not sit unconcern for the unexpected to happen. The colour of this headgear is red and the fabric used for it is velvet. The design, shape and colour of the symbols affixed to the headgear are in conformity. The symbols and fluffy nature of the velvet used for the headgear make it look attractive and pleasant. The projections on top of the headgear look extraordinary, gorgeous, colourful and fascinating.

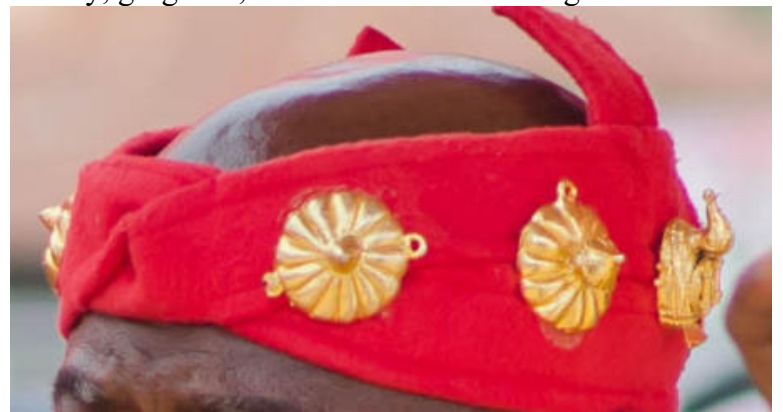

Figure.8: Me tena ho mma nfofoo nnane me kwaye headgear Source: Fieldwork

Skull Cap (kro bon ky\&)

Skull cap is one of the artefacts that is commonly used by most Akan traditional societies in Ghana. This type of cap is worn by sword bearers during festive occasions; and Akwantukese is no exception. The skull cap shown in Figure. 9 is one of the many types of cap used by sword bearers of the New Juaben state. The study indicated that this skull cap is known as kro bon kye in the Akan language. It is made of the rawhide of a buffalo. It was found that the sword bearers cap is worn to show the status of the bearer. For instance someone who has served for a number of years and is loyal. In support of this, Cole and Ross(1977) state that a skull cup is normally worn to show the rank of the bearer. The skull cap is circular in shape and looks like a calabash. It is coated with black colour and polished with lacquer. This particular skull cap is cream and black in colour and has been marbled. There is a leather band around the edge of the cap and it is coffee in colour. It was observed that the design on it looks tactile and has been embossed. This makes the cap appears to be weird, awful and dreadful. The artistic qualities such as the shape, colour and texture are in harmony and brings out its aesthetic value. In affirming this, Parsons (2004) mentioned that the formalist theory of aesthetics posits that an artefact is said to have 
aesthetic value when it has principles and elements of art such as shape, colour, texture, harmony, balance and rhythm.

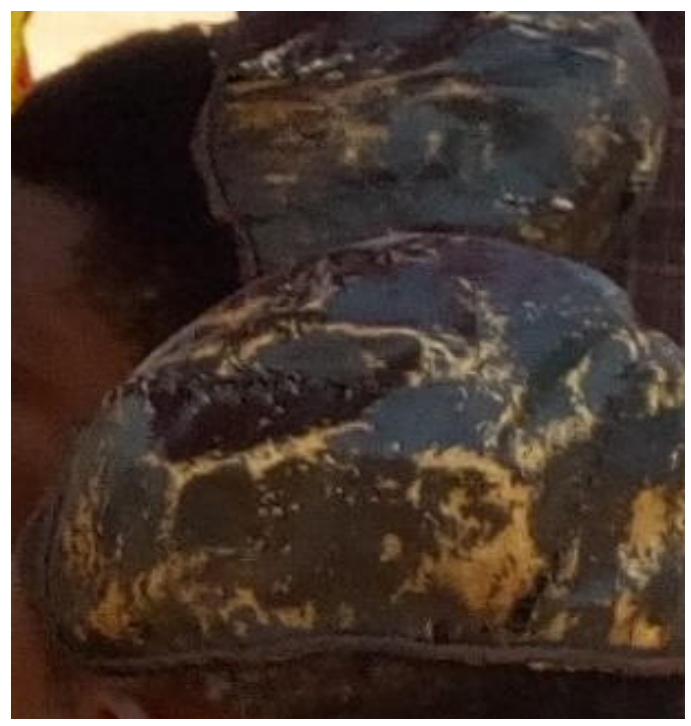

Figure.9 Skull cap ( $\boldsymbol{k r o}$ bon $\boldsymbol{k y \varepsilon})$

Source: Fieldwork

\section{Hand Ornament}

Human hands and fingers are the communicative parts of the body in the Asante culture. They play major roles in daily activities such as dancing and making of gestures. Chiefs and queen mothers in the New Juaben Traditional area usually wear hand ornaments during the Akwantukese festival. The objects in Figure.10 and FIGURE.11 are the hand ornaments that some chiefs wore during the festival celebration, as observed by the researchers. These hand ornaments are made of gold. The one in Plate 4.10 is called (skokodurofos a ba) meaning the brave one has come. This hand ornament has shapes like a horn, a shell of snail, and a jewelry box. The arrangements, shapes, colour and the design of these symbols appear extremely attractive. The royal blue, green and yellow colours of the fabric which were used to string the individual symbols makes the ornament pretty, attractive and pleasing. The study revealed that the hand ornaments displayed in Figure 10 is known as (nkabomu ma mpontuo). This is translated to mean unity brings development. These ornaments are spherical in shape with some vertical and horizontal lines around them. They are very pleasant and artistically pleasing to the eye. The designs, shapes and arrangement of the symbols are in harmony with each other. It was found that the designs of these ornaments are known as (awansena tire) the head of housefly and (abebee) sea snail. According to them, all these ornaments are used to beautify the chiefs in the New Juaben traditional and also to showcase their royalty and wealth.

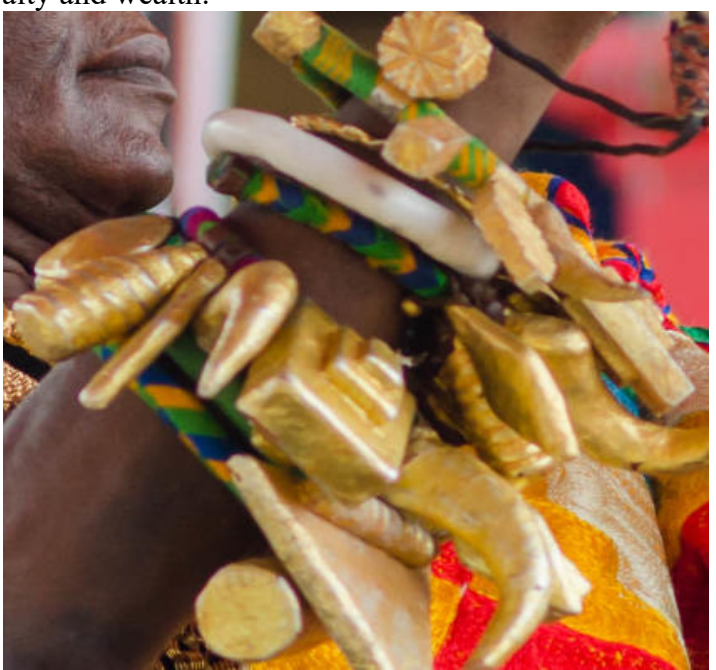

Figure 10 Hand ornament Source: Field

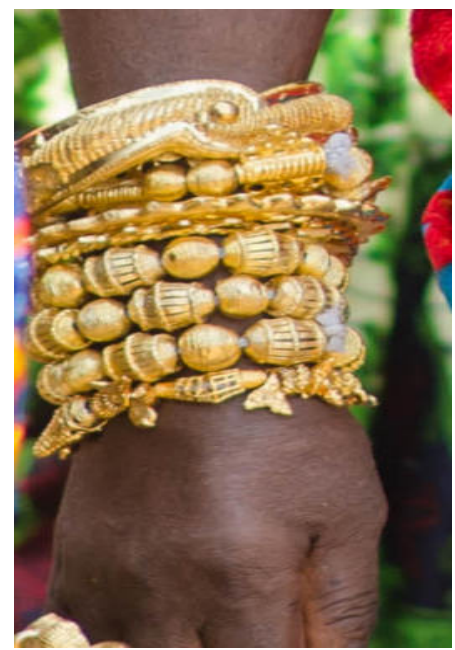

Figure 11 Hand ornament Source:Field 


\section{Native Sandals (ahenema)}

The native sandals(ahenema) is one of the most important insignia that chiefs and queen mothers do not joke with at all. The type of the native sandals that a chief or queen mother wears even shows his/her status in the traditional area. Figs 12 and 13 are some of the native sandals which were worn by some chiefs during Akwantukese festival celebration. The observation made revealed that the native sandals were made of leather and worn out lorry tyre. Thus the under part of the native sandals was taken from worn out lorry tyre and the top from the leather. To confirm this finding, Nana Yaw Opoku assert that the sole(down) part of the native sandals is obtained from lorry tyres that are no more in use. The top of the native sandal in Fig 12 was made of black leather with round cast gold ornament knobs on it whereas the sole(down) is painted black. The inside of the ahenema or native sandals is cream in colour and has black polish around it. The substance used for painting the native sandals is called mpaboaduro and it is obtained from a mixture of asphaltum and turpentine (Osei Akwasi, personal communication,28 October,2017). According to the respondents the name of the symbols on top of this native sandals in Fig 12 is known as "wo aka bi a twa so" which literary do not talk too much. The golden symbols attached to the top of the are in harmony with its sole and makes the whole object looks spectacular and outstanding. Information gathered from the study revealed that if a chief wear this type of native sandal (ahenema), during Akwantukese festival celebration, it indicates that the chief is powerful, discipline, prominent and wealthy. The shapes of the golden symbols affixed to the top of native sandals and the shape of the sole give it a pleasant look.

Similarly, information gathered showed that the native sandal in Fig 13 was also made from worn out lorry tyre and leather like the one discussed in Fig 12. The top of this particular native sandal was made with black leather strap and the sole too is black. The leather strap on top has some designs like dot on it. Also, this sandal has a circular knob with several strips like hair on it and the designs make the sandal appears awful and horrific. The inner of the sandal is dark brown in colour. The design and the symbol on top of it conveys both visual and verbal messages which educated the public. The data gathered indicated that the name of the symbol on top of the sandal is known as "abodwese betoo aniton nwi" which literary means eye brow was in existence before the beard came. This proverb means that elders were there before chiefs were enstooled and for that matter the chiefs have to respect the elders in order to bring peace and amity in our societies.

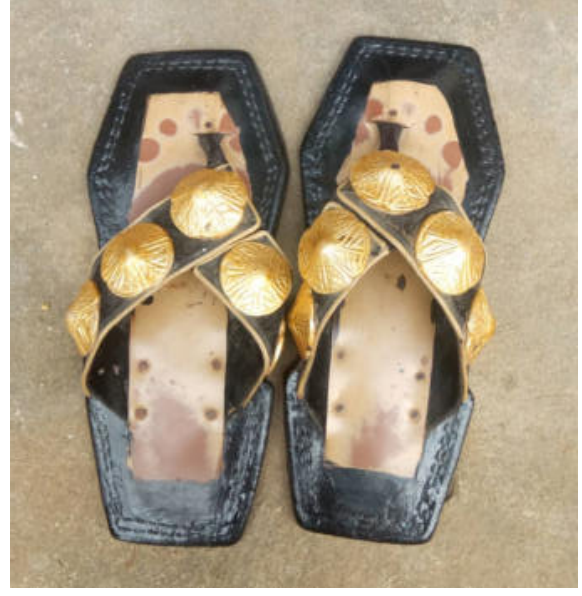

Fig 12 wo aka bi a twa so Source: Fieldwork

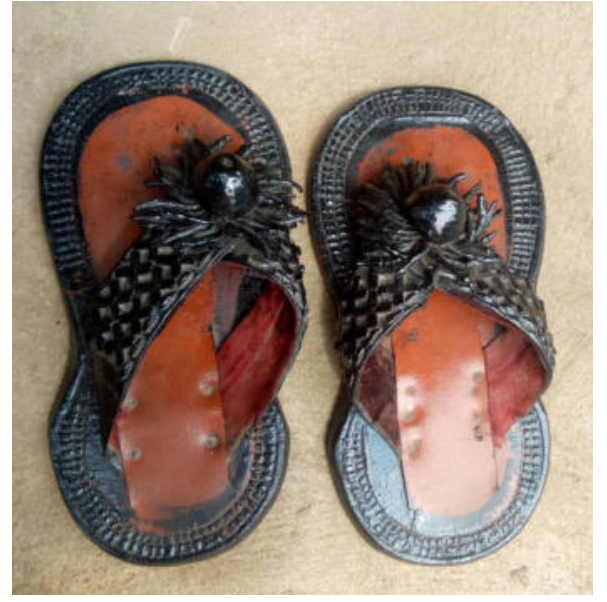

Fig 13 abodwese betoo aniton nwi Source: Fieldwork

An umbrella finial

During Akwantukese festival celebration, all the chiefs and queen mothers who attend bring along their umbrellas and these umbrellas have finials on top of them. One of the finials which was captured during the festival has been displayed in Figure 14. This finial has a symbol of a hawk (akoroma) which is a totem of the oyoko clan. The symbol was cast in gold and the textures on the symbol are visible. The lines used to create the textures are thick and bold and this makes the finial noticeable and eye-catching. It was found that the symbol on the umbrella stand for patience, endurance, tolerance and self-confidence. 


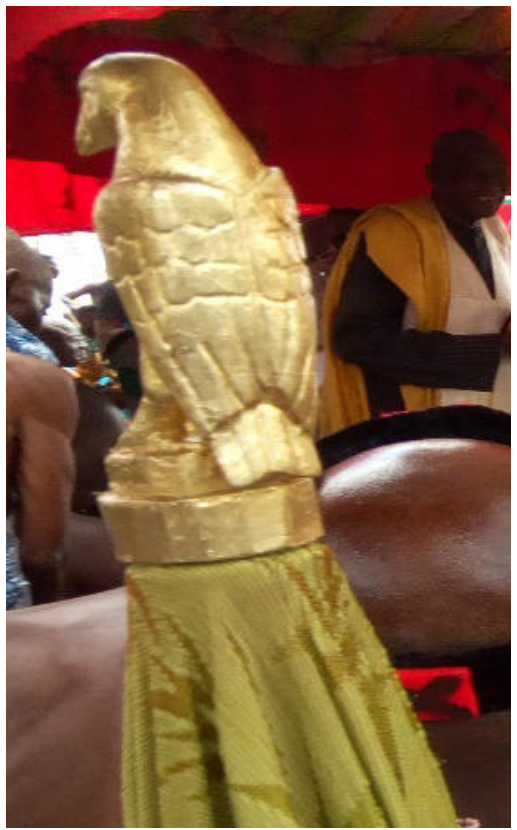

Figure 14:An umbrella finial Source: Fieldwork

\section{Conclusions}

The study is intended to make known the aesthetic values of the art forms that are embedded in the Akwantukese festival celebration. The conclusions drawn from the research are optimistic and indicate that the Akwantukese festival celebration is a possible platform for unveiling and debut the aesthetic values of the visual art forms embedded in it and appreciate them.

Also, the study shows that almost all the visual art forms seen in the festival celebration have aesthetic values and express emotions such as joy, happiness, grieve, sadness and others. Researchers who are interested in this kind of study should also conduct studies on the aesthetic values of the art forms used in other festival which is celebrated in any of the regions in Ghana to preserve the cultural heritage of the various Ghanaian societies for the transmission of Art education.

\section{Recommendations}

It is therefore recommended that the chiefs and the people of the New Juaben Traditional area should always take part in the festival celebration so that they can observe and appreciate the aesthetic values of the various visual art forms that are seen during the celebration.

Again, this study should be used in the teaching and learning of topics such as indigenous art forms, symbolism, creativity, art appreciation and others in the Senior High Schools in Ghana. The reason is that the study would widen the knowledge base of art teachers/educators, curators, researchers, historians among others.

Art educators and historians should come together and organize symposiums, conferences and workshops on cultural arts to alert heads and principals of schools and colleges, teachers and other stakeholders on the importance of the indigenous arts and their aesthetic values and how they can be appreciated in our societies.

\section{References}

Amenuke, S.K, Dogbe, B.K, Asare, F.D.K, Ayiku, R.K.\&Baffoe, A.1991. General Knowledge in Art for Senior Secondary Schools. London: Evans Brother Ltd.

Aumann, A.2014. The Relationship between Aesthetic Value and Cognitive Value. Journal of Aesthetics and Art criticism Vol.72.No 2, pp 117-127.

Creswell, J.W 2012. Planning, Conducting, and Evaluating Qualitative Research Fourth Edition by J. W Creswell. University of Nebraska-Lincoln.

Cudny, W. 2016. The Concept, Origins and Types of Festival. Springer International Publishing Switzerland Gyekye, K. 1996. African Cultural Values. An Introduction. Sankofa Publishing Company Accra, Ghana.

Jacquette, D. 2014.Art, Expression, Perception and Intentionality, Journal of Aesthetics and Phenomenology, $1,1,63-90$

Jisheng, X. 2001. The Mythology of Tibetan Mountain gods: An Overview. Retrieved on $3^{\text {rd }}$ June 17/06/2017 at 
https.// mospace.umsystem.edu/xmlui/bitstream/handle/10355/64830/Oral Tradition 16-2 Jisheng.

Kafle, N.P.2011.Hermenutic phenomenological research method simplified: Bodhi: An interdisciplinary Journal, 5(1), 181-200 https: //doi org/10.3126/bodi. v5Ii.8053

Kieran, M.2010. The vice of Snobbery: Aesthetic Knowledge, Justification and Virtue in Art

Appreciation. Philosophical Quarterly, 60, 243-263.

Kumekpor, T. K.B. 2002. Research methods and techniques of social research, Accra, Ghana: Son Life Press.

Lopes, D.M.2011.The Myth of (Non-Aesthetic) Artistic Value. The Philosophical Quarterly Vol.61 No. 244(July,2011), pp518-536. Published by Oxford University Press on behalf of the Scots Philosophical Association and University of St. Andrews.

Maggs-Rapport, F.2000. Combining methodological approaches in research: ethnography and interpretive phenomenology.

McLeod, M.D.1981. The court and regalia. Published by the British Museum Publications Ltd, 6 Bedford Square, London.

Osei-Bonsu, M. 2010. Stool Regalia of the Dwaben State of Asante (GHANA): RELEVANCE TO ART EDUCATION. A Dissertation submitted to the school of Graduate Studies, Kwame Nkrumah University of Science and Technology, Kumasi.

Prinz, J. 2007. Emotion and Aesthetic Value. In E. Schellekens \& P. Goldie(Eds.), The aesthetic mind: Philosophy and psychology(p.71-88) Oxford University Press.

Sandelowski, M. 2000. Focus on Research Methods Whatever Happened to Qualitative Description? https:// doi.org /10.1002/1098-240X (200008)23:4<334: AID-NUR>3.0.CO,2-G,

Stuhr, L.P.1994. Multicultural Art Education and social Reconstruction. Studies in Art Education, Vol.35.No 3, pp171-178.

Terrell, S.R.2016. Writing a Proposal for your Dissertation. Guidelines and Examples. Printed in U.S.A.

Yano, K.2008. Sacred Mountain Where Being of "Kami" is found. Published in Tokyo, Japan 